\title{
Colonic fermentation of complex carbohydrates in patients with familial adenomatous polyposis
}

\author{
D M Bradburn, J C Mathers, A Gunn, J Burn, P D Chapman, I D A Johnston
}

\begin{abstract}
Decreased production of butyric acid by colonic carbohydrate fermentation may predispose to colonic carcinogenesis, with the implicit assumption that the decrease in faecal butyrate found predates the development of the tumour. The influence of the genetic predisposition to colonic tumours and the presence of colonic polyps on in vitro fermentation of carbohydrates was examined. Stool samples from 11 normal controls and 20 patients with familial adenomatous polyposis (FAP) were incubated anaerobically with a range of carbohydrates. Fermentation patterns were similar for glucose and raffinose. These sugars produced different short chain fatty acid (SCFA) patterns from the two polysaccharides, starch and arabinogalactan, which differed one from the other. The FAP gene carriers with polyps produced less butyrate than normal controls $(p<0.005)$ and gene carriers without polyps $(p<0.05)$. There were corresponding decreases in the molar ratios of butyrate. Gene carriers without polyps produced less absolute amounts of acetate than normal controls $(p<0.05)$ and slightly less total SCFAs $(p<0.05)$ but were otherwise not significantly different. The decreased production of butyrate noted by other workers may be secondary to the tumours rather than a contributory cause.

(Gut 1993; 34: 630-636)
\end{abstract}

Epidemiology has stressed the importance of diet in the development of colorectal cancer. Diets high in complex carbohydrates seem to be protective, whereas those high in fat may have adverse effects. ${ }^{12}$ Despite this epidemiological evidence, the importance of diet remains unproved and possible mechanisms have been sought. Burkitt originally suggested that the increased faecal bulk and decreased transit time associated with a diet rich in plant cell walls (dietary fibre) diluted carcinogens and lessened the contact time with the colonic mucosa. ${ }^{3}$ The realisation that dietary fibre is fermented in the colon to short chain fatty acids (SCFAs) has led to alternative hypotheses. ${ }^{4}$

The production of SCFAs is associated with a reduction in $\mathrm{pH}$ that has been proposed to be a protective factor through an, as yet, uncertain mechanism..$^{5}$ Also, attention has focused on butyric acid, one of the SCFAs, which has antineoplastic properties in vitro. ${ }^{6}$ When added to malignant cell lines, butyrate is associated with the return of contact inhibition ${ }^{7}$ and the recovery of the morphological and functional characteristics associated with the parent cell. ${ }^{8}$ Decreased molar ratios of butyrate have been found in enema samples ${ }^{9}$ and in the faeces of patients with colonic cancers and polyps. ${ }^{10}$ Decreased butyrate production was reported in similar patient groups. " It has therefore been hypothesised that dietary fibre is protective by virtue of its production of butyric acid. ${ }^{\prime}$

For this hypothesis to be tenable, the reduction in butyrate must predate the development of tumours. We attempted to test this hypothesis with subjects with familial adenomatous polyposis (FAP). As subjects can be identified before polyps develop, ${ }^{12}$ it is possible to separate changes that predate polyp growth from those that appear after polyps develop.

\section{Patients and methods}

\section{SUBJECTS}

Thirty one subjects were recruited from the Northern Region Polyposis Registry. Table I shows that risk analysis allowed the patients to be divided into three groups. All gene carriers with polyps had a colonoscopy as had seven of 10 gene carriers with no polyps. The remainder of the second group had rigid sigmoidoscopy. One of the controls had colonoscopy and eight had rigid sigmoidoscopy. Two controls (ages 9 and 11) were children of a departmental member and were not endoscoped. No patient had received any antibiotics in the six weeks before the study. All subjects were on a mixed western diet and no dietary restrictions were imposed.

With the estimates of interindividual variation and between group differences in butyrate molar ratios given by Weaver et $a l,{ }^{9}$ it was calculated that 6-21 subjects in a group would provide an $80 \%$ power of detecting a true difference of the size reported by Weaver $e t a l^{9}$ at the $5 \%$ level of significance.

\section{SAMPLE COLLECTION AND PROCESSING}

Faecal samples were collected in the patient's own homes and were stored anaerobically in sealed evacuated plastic bags at $4^{\circ} \mathrm{C}$ for up to six hours until homogenisation by a stomacher (model 400, Seward Medical) for five minutes. After pH measurement (Corning, model 245), duplicate $1 \mathrm{~g}$ portions were taken for SCFA analysis and frozen. A further $20 \mathrm{~g}$ sample was taken and stored anaerobically under $\mathrm{CO}_{2}$ at $4^{\circ} \mathrm{C}$ overnight in preparation for in vitro fermentation.

\section{IN VITRO BATCH CULTURE}

Faeces $(20 \mathrm{~g})$ were homogenised with $125 \mathrm{ml}$ of buffer ${ }^{13}$ at $37^{\circ} \mathrm{C}$ and filtered through a single layer of muslin. Five millilitres of filtered slurry and $10 \mathrm{ml}$ of buffer with either no carbohydrate 
TABLE I Risk of familial adenomatous polyposis (FAP) gene carriage ${ }^{12}$ and ages of the study population

\begin{tabular}{|c|c|c|c|}
\hline Group & No & $\begin{array}{l}\text { Risk of gene } \\
\text { carriage } \\
(\%)\end{array}$ & $\begin{array}{l}\text { Mean age } \\
\text { (range) } \\
(y)\end{array}$ \\
\hline Control & $\begin{array}{l}5 M \\
6 \mathrm{~F}\end{array}$ & $<1$ & $25 \cdot 6(9-53)$ \\
\hline $\begin{array}{l}\text { FAP gene carriers with no } \\
\text { polyps }\end{array}$ & $\begin{array}{l}3 \mathrm{M} \\
7 \mathrm{~F}\end{array}$ & $>98$ & $22 \cdot 3(7-53)$ \\
\hline $\begin{array}{l}\text { FAP gene carriers with } \\
\text { polyps }\end{array}$ & $\begin{array}{l}7 \mathrm{M} \\
3 \mathrm{~F}\end{array}$ & 100 & $19 \cdot 9(11-32)$ \\
\hline
\end{tabular}

TABLE II Analysis of variance model for testing the outlined experimental hypotheses

\begin{tabular}{|c|c|}
\hline Source of variation & $\begin{array}{l}\text { Degrees of } \\
\text { freedom }\end{array}$ \\
\hline \multicolumn{2}{|l|}{ Main plot: } \\
\hline Between groups & 2 \\
\hline Control $v$ FAP gene carriers & 1 \\
\hline No polyps $v$ polyps & 1 \\
\hline Between subjects within groups (error 1) & 28 \\
\hline Main plot total & 30 \\
\hline \multicolumn{2}{|l|}{ Sub-plot: } \\
\hline Between substrates & 3 \\
\hline Sugars $v$ polysaccharides & 1 \\
\hline Starch $v$ arabinogalactan & 1 \\
\hline Glucose $v$ raffinose & 1 \\
\hline Group $\times$ substrate interaction & $6^{\star}$ \\
\hline Error 2 & 80 \\
\hline Sub-plot total & 89 \\
\hline Grand total & 119 \\
\hline
\end{tabular}

$\star$ This interaction was also split into its six single degree of freedom contrasts defined by the primary contrasts.

(blank) or $250 \mathrm{mg}$ of starch (soluble potato starch, Sigma S2630), arabinogalactan (larch wood, Sigma A9029) glucose (Sigma, G8270) or raffinose (Sigma R250) were placed in $25 \mathrm{ml}$ McCartney bottles. Incubation bottles were gassed with $\mathrm{CO}_{2}$, sealed with a Suba seal and vented with a hypodermic needle. Duplicate incubations were performed in an orbital shaker (Gallenkamp) at $37^{\circ} \mathrm{C}$ and $125 \mathrm{rpm}$. Samples for SCFA analysis were removed after 24 hours.

\section{SCFA ANALYSIS}

The SCFAs were measured as previously described. ${ }^{14}$ Duplicate samples were deproteinised with $20 \%$ metaphosphoric acid (2:1 w/v) containing 3 methyl valeric acid $(50 \mathrm{mM})$ as an internal standard. Analysis was performed in duplicate by gas chromatography (Pye Unicam P4550, $1.5 \mathrm{~m} \times 2 \mathrm{~mm}$ internal diameter column, Chromosorb 80/100 packing (Supelco Bellforte PA 16823 USA), $\mathrm{N}_{2}$ carrier gas, flow rate $55 \mathrm{ml} / \mathrm{min}$ at $125^{\circ} \mathrm{C}$ ).

STATISTICS

All statistics were performed by analysis of

TABLE III The influence of storage on faecal short chain fatty acids (SCFAs)

\begin{tabular}{|c|c|c|c|c|c|c|c|}
\hline \multirow[b]{2}{*}{$\begin{array}{l}\text { Storage time } \\
\text { (h) }\end{array}$} & \multicolumn{4}{|c|}{ SCFA (mMol/kg faeces) } & \multicolumn{3}{|c|}{ Molar ratio $(\mathrm{mMol} / \mathrm{mol})$} \\
\hline & Acetate & Propionate & Butyrate & Total & Acetate & Propionate & Butyrate \\
\hline $\begin{array}{l}0 \\
3 \\
6 \\
\text { Pooled error }\end{array}$ & $\begin{array}{l}75 \cdot 3 \\
77 \cdot 5 \\
74 \cdot 6 \\
11 \cdot 91\end{array}$ & $\begin{array}{c}20.3 \\
20.9 \\
20.5 \\
3.93\end{array}$ & $\begin{array}{c}31 \cdot 5 \\
35 \cdot 0 \\
35 \cdot 7 \\
7 \cdot 15\end{array}$ & $\begin{array}{l}133 \cdot 7 \\
139 \cdot 5 \\
136 \cdot 7 \\
10 \cdot 40\end{array}$ & $\begin{array}{l}565 \\
557 \\
548 \\
16 \cdot 2\end{array}$ & $\begin{array}{l}152 \\
150 \\
150 \\
3.4\end{array}$ & $\begin{array}{l}236 \\
249 \\
258 \\
12 \cdot 6\end{array}$ \\
\hline
\end{tabular}

Total SCFA includes values for isobutyrate, isovalerate, and valerate (not presented). variance with the Genstat $\mathrm{V}$ package for the mainframe computer. Differences between groups were tested by orthogonal contrasts (Table II). For the main part of the study the hypotheses were that: $(a)$ there is no difference between controls and subjects with the FAP gene; $(b)$ there is no difference between FAP gene carriers with and without polyps.

The other hypotheses tested were that: $(c)$ there is no difference between controls and FAP gene carriers with no polyps; $(d)$ there is no difference between controls and FAP gene carriers with polyps.

Also, where different substrates (glucose, raffinose, starch, and arabinogalactan) were used for in vitro incubations and tested within each subject, substrate effects were treated as a subplot. Hypotheses concerning differences between substrates and possible group $\times$ substrate interactions were tested by orthogonal contrasts (Table II). The contrast arabinogalac$\tan \times$ other carbohydrates was also tested.

\section{Results}

THE EFFECT OF ANAEROBIC STORAGE FOR SIX HOURS ON FAECAL SCFAS

Four separate stool samples from the same donor were stored at $4^{\circ} \mathrm{C}$ for six hours. Storage had no effect on the absolute amounts of molar proportions of SCFAs in faecal samples over a six hour period (Tables III and IV).

THE EFFECT OF ANAEROBIC STORAGE FOR 24 HOURS ON IN VITRO PRODUCTION OF SCFAS The net production of SCFAs attributed to the fermentation of the added carbohydrate was calculated by subtraction of the corresponding blank value from the one with added carbohydrate. All the SCFA values presented are net values.

Storage for 24 hours before initiating incubation with the test carbohydrates had no significant effect on the SCFAs produced (Tables $V$ and VI). There were, however, noticeable trends towards decreased butyrate and increased acetate after storage. To minimise differences due to storage in the main experiment, all samples were stored for similar periods of time (18-24 hours) before incubation.

FAECAL PH, PERCENTAGE DRY MATTER, SCFA CONCENTRATION, AND MOLAR RATIOS There was no difference in the dry matter content of stool samples between the three groups (Table VII). Likewise there were no differences in the absolute concentrations or relative proportions of acetate, propionate, or butyrate (Table VIII). There were no differences in faecal $\mathrm{pH}$

TABLE IV Analysis of variance for data in Table III

\begin{tabular}{ll}
\hline Source of variation & Degrees of freedom \\
\hline Stool sample & 3 \\
Storage time & 2 \\
Stool $\times$ storage time interaction (error) & 6
\end{tabular}


TABLE $\mathrm{V}$ The effect of storage of stool samples for $24 \mathrm{~h}$ on the in vitro fermentation of carbohydrate

\begin{tabular}{|c|c|c|c|c|c|c|c|c|c|}
\hline \multirow[b]{2}{*}{ Substrate } & \multicolumn{6}{|c|}{ SCFA (mMol/l in incubation fluid) } & \multicolumn{3}{|c|}{ Molar ratio $(\mathrm{mMol} / \mathrm{mol})$} \\
\hline & $\begin{array}{l}\text { Storage } \\
\text { period }(h)\end{array}$ & $\begin{array}{l}\text { Incubation } \\
\text { period }(h)\end{array}$ & Acetate & Propionate & Butyrate & Total & Acetate & Propionate & Butyrate \\
\hline $\begin{array}{l}\text { Starch } \\
\text { Arabinogalactan } \\
\text { Glucose } \\
\text { Starch } \\
\text { Arabinogalactan } \\
\text { Glucose } \\
\text { Pooled error } \\
\text { Probability }\end{array}$ & $\begin{array}{r}0 \\
0 \\
0 \\
24 \\
24 \\
24\end{array}$ & $\begin{array}{l}24 \\
24 \\
24 \\
24 \\
24 \\
24\end{array}$ & $\begin{array}{l}46 \cdot 6 \\
31 \cdot 1 \\
47 \cdot 6 \\
54 \cdot 0 \\
29 \cdot 2 \\
69 \cdot 2 \\
4 \cdot 43 \\
\text { NS }\end{array}$ & $\begin{array}{l}9 \cdot 8 \\
6 \cdot 3 \\
8 \cdot 7 \\
9 \cdot 3 \\
6 \cdot 8 \\
8 \cdot 3 \\
0 \cdot 64 \\
\text { NS }\end{array}$ & $\begin{array}{c}40 \cdot 4 \\
6 \cdot 5 \\
47 \cdot 8 \\
30 \cdot 4 \\
6 \cdot 1 \\
27 \cdot 2 \\
5 \cdot 09 \\
\text { NS }\end{array}$ & $\begin{array}{c}96 \cdot 9 \\
45 \cdot 5 \\
103 \cdot 9 \\
93 \cdot 7 \\
44 \cdot 1 \\
104 \cdot 5 \\
4 \cdot 07 \\
\text { NS }\end{array}$ & $\begin{array}{l}480 \\
684 \\
458 \\
577 \\
662 \\
663 \\
47 \cdot 5 \\
\text { NS }\end{array}$ & $\begin{array}{c}102 \\
138 \\
84 \\
99 \\
154 \\
80 \\
3 \cdot 4 \\
\mathrm{NS}\end{array}$ & $\begin{array}{c}417 \\
142 \\
460 \\
324 \\
137 \\
261 \\
47 \cdot 7 \\
\text { NS }\end{array}$ \\
\hline
\end{tabular}

Abbreviations and footnotes as for Table III.

TABLE VI Analysis of variance for data in Table $V$

\begin{tabular}{ll}
\hline Source of variation & $\begin{array}{l}\text { Degrees of } \\
\text { freedom }\end{array}$ \\
\hline Main plot: & \\
Stool sample & 3 \\
Storage time & 1 \\
Stool $\times$ storage time interaction (error 1) & 3 \\
$\quad$ Main plot total & 7 \\
Sub-plot: & 2 \\
Substrate & 2 \\
Substrate $\times$ storage time interaction & 12 \\
Error 2 & 23 \\
Total & \\
\hline
\end{tabular}

TABLE VII Dry matter content of stools as determined by freeze drying to constant weights (differences are $N S$ )

\begin{tabular}{llll}
\hline & \multicolumn{2}{l}{$\begin{array}{l}\text { Mean dry } \\
\text { weight })\end{array}$} \\
\cline { 2 - 4 } Group & Mean & Range & $S E$ \\
\hline Control content of stool $(\%$ wet \\
FAP with no polyps & $30 \cdot 0$ & $20 \cdot 0-56 \cdot 6$ & $2 \cdot 94$ \\
FAP with polyps & $28 \cdot 2$ & $14 \cdot 5-32 \cdot 7$ & $1 \cdot 82$ \\
\hline
\end{tabular}

PRODUCTION OF SCFAS FROM STARCH, ARABINOGALACTAN, GLUCOSE, AND RAFFINOSE All substrates were fermented to produce SCFAs. Time courses of SCFA production were run for all subjects and Fig I shows an illustrative example for starch fermentation by a control subjects. There were differences between substrates in the patterns of SCFAs produced (Table IX, Fig 2). Arabinogalactan produced less total SCFAs than the others $(p<0.001)$ due to decreases in the absolute amounts of acetate $(\mathrm{p}<0.001)$, and butyrate $(\mathrm{p}<0.001)$. It resulted, however, in relatively larger molar proportions of propionate $(p<0.001)$ and smaller proportions of butyrate $(\mathrm{p}<0.001)$. Glucose produced more total SCFA than did starch $(\mathrm{p}<0.001)$ with a decrease in the molar ratio of acetate $(\mathrm{p}<0.001)$ and an increase in butyrate $(\mathrm{p}<0.001)$.

TABLE VIII The absolute amounts and molar ratios of SCFAs and pH in faeces

\begin{tabular}{|c|c|c|c|c|c|c|c|c|}
\hline \multirow[b]{2}{*}{ Group } & \multicolumn{4}{|c|}{ SCFA (mMol/kg faeces) } & \multicolumn{3}{|c|}{ Molar ratio $(\mathrm{mMol} / \mathrm{mol})$} & \multirow[b]{2}{*}{$p H$} \\
\hline & Acetate & Propionate & Butyrate & Total & Acetate & Propionate & Butyrate & \\
\hline $\begin{array}{l}\text { Control } \\
\text { FAP with no polyps } \\
\text { FAP with polyps } \\
\text { Pooled error }\end{array}$ & $\begin{array}{l}76 \cdot 3 \\
88 \cdot 5 \\
86 \cdot 1 \\
17 \cdot 97\end{array}$ & $\begin{array}{c}29 \cdot 4 \\
33 \cdot 1 \\
33 \cdot 7 \\
8 \cdot 60\end{array}$ & $\begin{array}{l}34 \cdot 5 \\
33 \cdot 2 \\
38 \cdot 3 \\
11 \cdot 42\end{array}$ & $\begin{array}{c}155 \cdot 4 \\
171 \cdot 3 \\
175 \cdot 7 \\
40 \cdot 01\end{array}$ & $\begin{array}{l}520 \\
524 \\
500 \\
28 \cdot 5\end{array}$ & $\begin{array}{l}185 \\
197 \\
195 \\
14 \cdot 1\end{array}$ & $\begin{array}{l}193 \\
189 \\
200 \\
24 \cdot 9\end{array}$ & $\begin{array}{l}6 \cdot 46 \\
6 \cdot 43 \\
6 \cdot 37 \\
0 \cdot 15\end{array}$ \\
\hline
\end{tabular}

Abbreviations and footnotes as for Table III.

TABLE IX Absolute amounts and molar ratios of SCFAs produced after in vitro incubation for $24 \mathrm{~h}$ with starch, arabinogalactan, glucose, or raffinose

\begin{tabular}{|c|c|c|c|c|c|c|c|}
\hline \multirow[b]{2}{*}{ Substrate } & \multicolumn{4}{|c|}{ SCFA (mMolll in incubation fluid) } & \multicolumn{3}{|c|}{ Molar ratio $(\mathrm{mMol} / \mathrm{mol})$} \\
\hline & Acetate & Propionate & Butyrate & Total & Acetate & Propionate & Butyrate \\
\hline \multicolumn{8}{|l|}{ Control: } \\
\hline Starch & $50 \cdot 7$ & $10 \cdot 1$ & $18 \cdot 0$ & $78 \cdot 5$ & 664 & 121 & 218 \\
\hline Arabinogalactan & $34 \cdot 0$ & 9.9 & $5 \cdot 3$ & $50 \cdot 0$ & 690 & 189 & 101 \\
\hline Glucose & $49 \cdot 6$ & $10 \cdot 8$ & $21 \cdot 2$ & $82 \cdot 7$ & 617 & 129 & 255 \\
\hline Raffinose & $52 \cdot 4$ & $9 \cdot 8$ & $20 \cdot 0$ & $83 \cdot 7$ & 631 & 117 & 249 \\
\hline \multicolumn{8}{|l|}{ No polyps: } \\
\hline Starch & $40 \cdot 7$ & $7 \cdot 8$ & $12 \cdot 2$ & $60 \cdot 9$ & 690 & 116 & 190 \\
\hline Arabinogalactan & $27 \cdot 8$ & 8.9 & $5 \cdot 2$ & $42 \cdot 4$ & 653 & 209 & 124 \\
\hline Glucose & $35 \cdot 8$ & $8 \cdot 0$ & $22 \cdot 3$ & $66 \cdot 8$ & 549 & 115 & 327 \\
\hline Raffinose & $38 \cdot 2$ & $8 \cdot 5$ & $19 \cdot 9$ & $67 \cdot 1$ & 570 & 126 & 298 \\
\hline \multicolumn{8}{|l|}{ Polyps: } \\
\hline Starch & $54 \cdot 2$ & $4 \cdot 6$ & $4 \cdot 0$ & $62 \cdot 4$ & 878 & 70 & 59 \\
\hline Arabinogalactan & $31 \cdot 4$ & $6 \cdot 5$ & $3 \cdot 0$ & $41 \cdot 7$ & 737 & 164 & 79 \\
\hline Glucose & $58 \cdot 8$ & $5 \cdot 1$ & $10 \cdot 3$ & $74 \cdot 0$ & 797 & 67 & 139 \\
\hline Raffinose & $56 \cdot 6$ & $6 \cdot 2$ & $12 \cdot 7$ & $75 \cdot 6$ & 754 & 83 & 166 \\
\hline Pooled error & 3.65 & 1.54 & $2 \cdot 66$ & $4 \cdot 72$ & $39 \cdot 34$ & $18 \cdot 72$ & $31 \cdot 04$ \\
\hline \multicolumn{8}{|l|}{ Main plot contrasts: } \\
\hline Polyps $v$ no polyps & 0.001 & NS & 0.011 & NS & 0.001 & 0.054 & 0.001 \\
\hline Control $v$ gene & NS & NS & 0.023 & 0.017 & NS & NS & NS \\
\hline Control $v$ polyps & NS & 0.028 & 0.002 & 0.072 & 0.002 & NS & 0.004 \\
\hline Control $v$ no polyps & 0.01 & NS & NS & 0.016 & NS & NS & NS \\
\hline \multicolumn{8}{|l|}{ Sub-plot contrasts: } \\
\hline $\begin{array}{l}\text { Polyps } v \text { no polyps between arabinogalactan } \\
\text { and other carbohydrates }\end{array}$ & 0.001 & NS & $0 \cdot 048$ & NS & $0 \cdot 012$ & NS & $0 \cdot 014$ \\
\hline $\begin{array}{l}\text { Control } v \text { polyps between arabinogalactan } \\
\text { and other carbohydrates }\end{array}$ & NS & NS & 0.008 & NS & 0.01 & NS & 0.022 \\
\hline
\end{tabular}

Abbreviations and footnotes as for Table III. 
Figure 1: Sample time course of SCFA production from starch for one control subject.

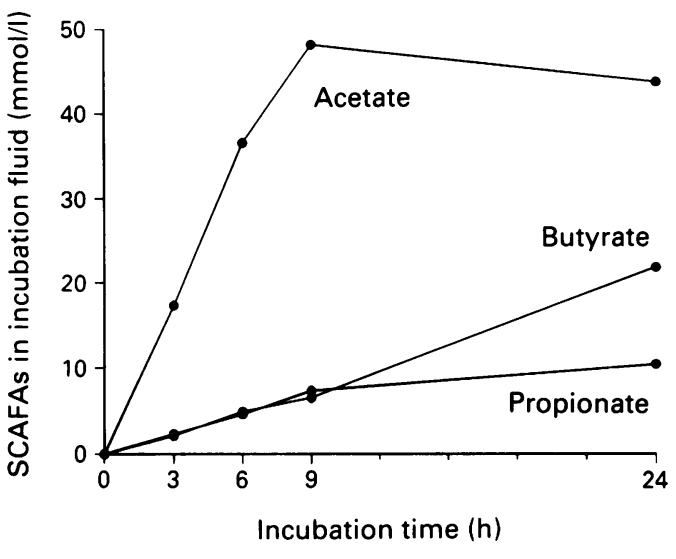

COMPARISON OF THE FERMENTATION BY THE SUBJECT GROUPS

Comparison of SCFA production by the different subject groups showed considerable differences (Table IX, Fig 3). Compared with normal controls, gene carriers without polyps produced less total SCFA $(p=0.016)$ with a reduction in the absolute amount of acetate $(p=0.01)$ but no
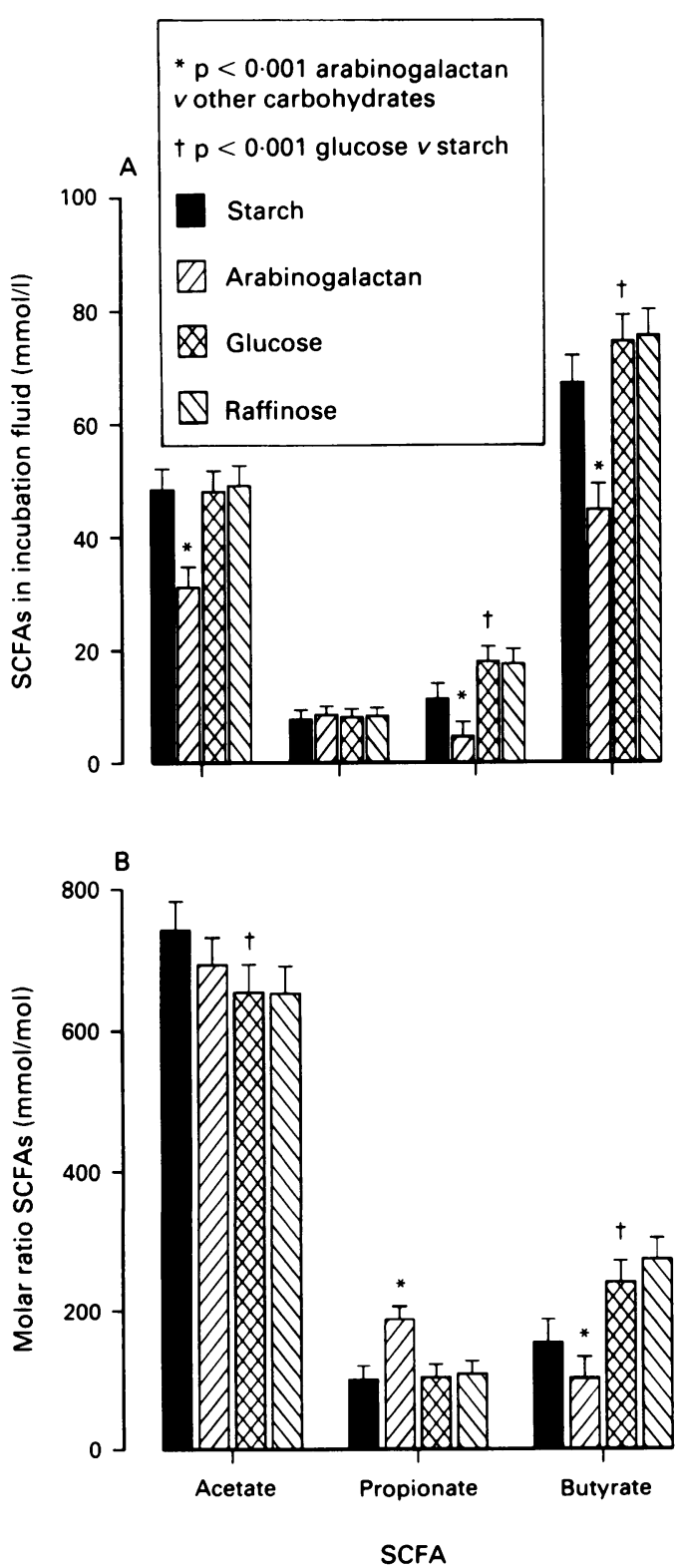
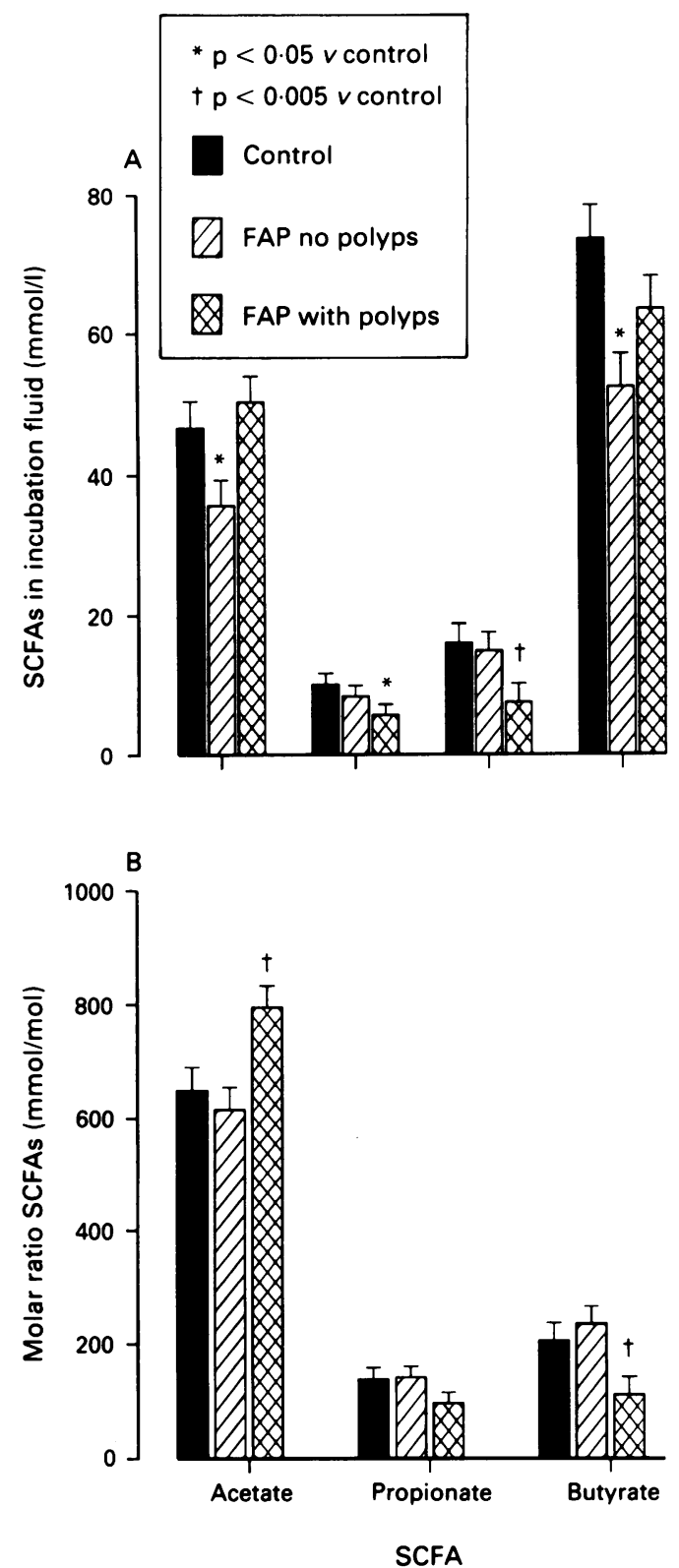

Figure 3: Comparison of $(A)$ net concentrations and $(B)$ molar ratios of SCFAs produced after 24 hours incubation by controls, gene carriers with no polyps, and gene carriers with polyps (means $(S E)$ ). Total SCFA includes values for isobutyrate, isovalerate, and valerate (not presented). Values shown are means of all four carbohydrates shown in Table $I X$ with significance values from ANOVA and orthogonal contrasts.

difference in the molar ratio of acetate, propionate, or butyrate.

Comparison, however, of normal controls and gene carriers with polyps showed a different pattern of changes. There was a slight nonsignificant decrease in the total SCFA produced by those patients with polyps $(\mathrm{p}=0 \cdot 072)$. The absolute concentrations of both propionate $(p=0.028)$ and butyrate $(p=0.002)$ were decreased. The molar proportion of acetate was increased $(p=0.002)$ whereas that of butyrate was decreased $(p=0.004)$ and there was evidence of a slight, non-significant, fall in propionate $(p=0.067)$. Gene carriers with and without polyps showed opposite changes in fermentation patterns when compared with normal controls. Consequently comparison of the two FAP groups showed considerable differences. There were no 
differences in the total SCFA produced, but gene carriers with polyps produced significantly larger molar ratios of acetate $(p<0.001)$ and smaller ratios of butyrate $(\mathrm{p}<0.001)$ and propionate $(p=0.054)$ than did those with no polyps.

\section{INTERACTIONS BETWEEN THE SUBJECT GROUP AND SUBSTRATE ON FERMENTATION END \\ PRODUCTS}

There were relatively few significant interactions between subject group and substrates. The apparent effect of the presence of polyps on the SCFA pattern was different with arabinogalactan compared with other substrates. The reduction of butyrate in the presence of polyps that was noted for the other carbohydrates was not detected with arabinogalactan (Table IX, Fig 4). Likewise the corresponding increase in acetate with polyps with other carbohydrates was not as obvious with arabinogalactan. There were no other significant group $\times$ substrate interactions.

CORRELATION BETWEEN AGE OF ONSET OF POLYPS AND FAECAL BUTYRATE

Within gene carriers with polyps there was no relation between the age of onset of macroscopic polyposis and the faecal butyrate (absolute amounts or molar ratios) or its in vitro production (absolute amounts or molar ratios).

\section{Discussion}

Most studies in humans of dietary influences on the development of colonic cancer have relied on population epidemiological surveys or casecontrol studies. Both these methods have limitations and neither can prove causality. In casecontrol studies attributing a change in a variable to the cause, rather than the result, of the tumour is particularly difficult.

Familial adenomatous polyposis is a unique human model in which to study the development of colonic cancer. Affected subjects have a defect on chromosome $5^{15}$ that initiates adenomatous change but, in common with sporadic cancers, the colonic mucosal cells are thought to undergo at least four other genetic changes before a cancer can develop. ${ }^{16}$ Environmental factors of importance in the development of sporadic colonic cancer are likely to act by influencing this sequence of changes. Subjects with FAP show a wide spread of ages when polyps first develop. ${ }^{17}$ This suggests that there may be similar environmental effects in FAP. The model is advantageous as gene carriers can be identified before polyps develop ${ }^{12}$; as a result, changes that predate, and therefore may promote, polyp growth may be investigated. Furthermore it provides an ideal study group for future dietary intervention studies.

Although the epidemiological evidence suggests a protective role for dietary complex carbohydrate in the aetiology of colorectal cancer, this has not been proved. To this end, a possible mode of action has been sought and recent studies have focused on the production of SCFAs by colonic fermentation of carbohydrates.9-11 These are present in considerable concentrations
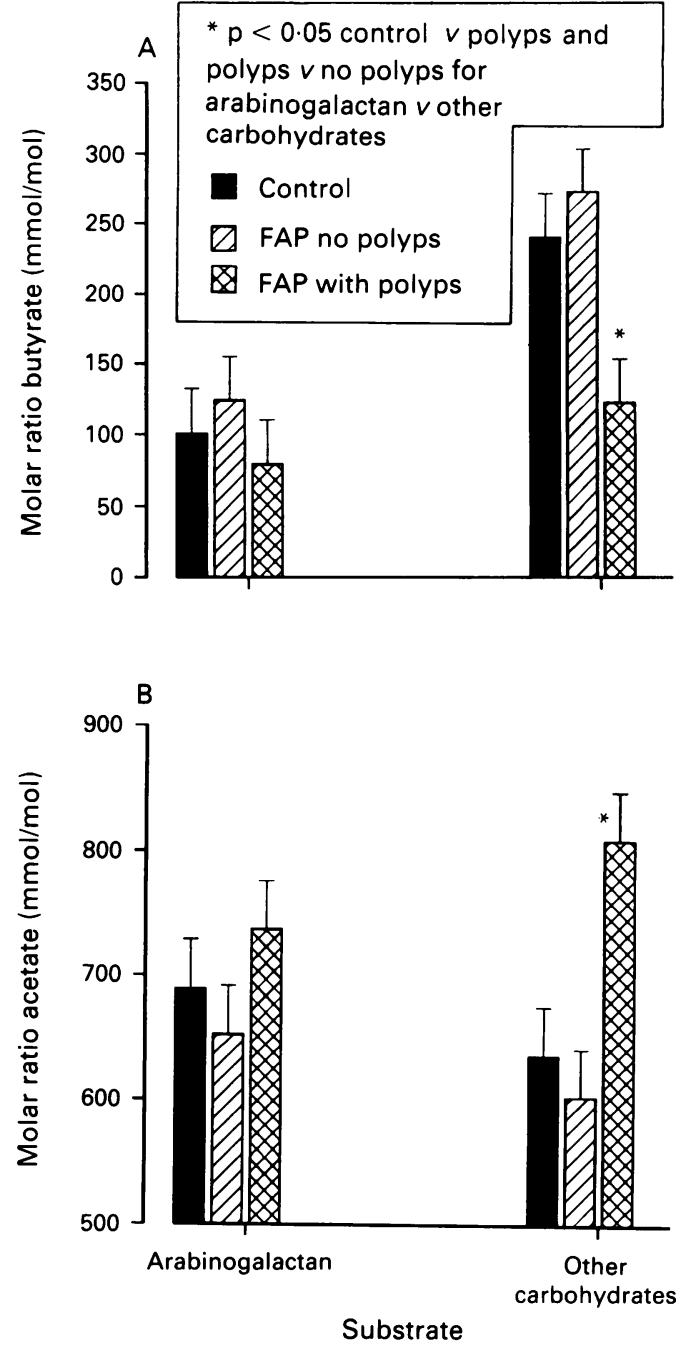

Figure 4: Subject group by substrate interactions in the production of $(A)$ butyrate and $(B)$ acetate. Figures presented are molar ratios $(S E)$. SCFA figures for other carbohydrates are means for starch, glucose, and raffinose shown in Table $I X$ and significance values are from ANOVA and orthogonal contrasts.

in the faeces and approximately $300 \mathrm{mmol}$ a day are produced. ${ }^{18}$ They are important in salt and water absorption from the colon, ${ }^{19}$ and butyric acid, one of the SCFAs, is the most important respiratory fuel for the colonic mucosa. ${ }^{18}$

The reduction in $\mathrm{pH}$ associated with the production of SCFAs has been proposed as a protective factor ${ }^{5}$ as a higher faecal $\mathrm{pH}$ has been noted in high risk populations. ${ }^{20}$ Some studies have shown high faecal $\mathrm{pH}$ in persons with colonic cancer, ${ }^{21}$ although others have failed to confirm these findings. ${ }^{22}$ We detected no differences in faecal $\mathrm{pH}$ in our three subject groups suggesting that neither the FAP gene nor the presence of polyps influences faecal $\mathrm{pH}$.

Interest has recently focused on the role of butyric acid in the development of colonic cancer. This compound has antineoplastic properties in vitro ${ }^{6}$ and decreased molar proportions have been found in faecal and enema samples from patients with colonic cancers and polyps. ${ }^{910}$ Furthermore decreased butyrate has been noted in similar patient groups with an in vitro model of caecal metabolism. " The apparently decreased caecal starch delivery in polyp formers ${ }^{23}$ gives 
further support to the hypothesis, as it seems that starch fermentation results in relatively larger concentrations of butyric acid..$^{24}$

We found no changes in the in vivo faecal SCFAs in subjects with FAP; furthermore we could not show any association of polyps with the faecal SCFA pattern. We did, however, show different SCFA production with the in vitro model. This apparent discrepancy has been noted by other workers ${ }^{11}$ and is probably a consequence of the poor reflection of total SCFA production afforded by the faecal SCFA profile. Alternatively, it may represent the variability of SCFA production in vivo between subjects and the variability within subjects over time due to dietary factors. Whereas it is possible that different proportions of dry matter in stool samples could lead to different sizes of bacterial inoculum for in vitro culture, there were no such differences between the three groups in the present study, so this is unlikely to have been a confounding factor.

Our data, from the in vitro model, confirm earlier findings that different carbohydrates are fermented to give different patterns of SCFAs. ${ }^{1424} 25$ This may in the future allow dietary manipulation of the intracolonic environment. We showed influences of both FAP gene carriage and the presence of polyps on the pattern of SCFAs produced. The FAP gene carriers without polyps produced less acetate and less total SCFA than normal controls. This has not previously been reported and the explanation for it is unclear. Previous workers have noted abnormalities in colonic cholesterol metabolism in FAP, ${ }^{26}$ and changes in both faecal ${ }^{27}$ and duodenal ${ }^{28}$ bile acid profiles have been recorded. Bile acids are known to alter faecal microbial growth ${ }^{29}$ and the influence of bile acids on fermentation may explain the changes noted. Alternatively in the light of recent evidence showing in vivo interations between colonic fermentation of starch and bile acid transformations $\mathrm{s}^{30}$ it is possible that the altered fermentation in FAP gene carriers without polyps is a primary change that may then influence bile acid transformations and may explain the results of other workers. It is not possible to conclude from our data whether the altered fermentation has any role in the progression of polyps but it is possible that the interaction of fermentation and bile acid metabolism may decrease secondary bile acids that are known promoters of colonic cancers. ${ }^{31}$

Polyps also seem to affect the fermentation patterns of carbohydrates. The changes in SCFAs associated with polyps in our study are similar to those noted by other workers in enema ${ }^{9}$ and faecal samples ${ }^{10}$ and with in vitro models. ${ }^{11}$ It is possible that the changes noted by these workers were secondary to the presence of polyps rather than a contributory factor in their development. Alternatively the FAP gene carriers may be a heterogeneous group in which the early appearance of polyps is linked with reduced colonic butyrate. We showed no correlation. between the age of onset of polyps and the faecal butyrate or the in vitro production of butyrate. This might be tested through a prospective study in which FAP gene carriers without polyps are divided into high and low butyrate groups and followed up until polyps develop.

Clausen et al considered the problem of causality by studying patients with sporadic neoplasms after colonic resection or endoscopic polypectomy and showed a reduction in the velocity of production of butyrate in affected patients. ${ }^{11}$ As the tumours had been removed it is not immediately possible to ascribe their results to an effect of polyps or cancers. All their subjects, however, had undergone bowel purgation, colectomy, or endoscopic polypectomy. The influence of these procedures on the microbial activity is not known and this difference in experimental protocol may explain the apparent disagreement with our results.

In conclusion we have identified different fermentation patterns in persons with FAP and an effect of polyps on the in vitro fermentation of carbohydrates. Furthermore we have shown that different carbohydrates produce different patterns of SCFA and that there may be interactions between host genotype and colonic fermentation. The role of colonic fermentation on the initiation and progression of colonic polyps merits further investigation, as this process is amenable to dietary manipulation.

Mr D M Bradburn is funded by the Northern Regional Health Authority, Locally Organised Research Scheme. Mrs P Chapman is funded by Imperial Cancer Research Fund.

1 Bingham SA. Mechanisms and experimental and epidemiological evidence relating dietary fibre (non starch polysaccharides) and starch to protection against large bowel cancer. Proc Nutr Soc 1990; 49: 153-71.

2 Willett $W$. The search for the causes of breast and colon cancer. Nature 1989; 338: 398-94.

3 Burkitt D, Walker AR, Painter NF. Effects of dietary fibre on stools and transit time and its role on the causation of disease. Lancet 1972; 2: 1408.

4 Jass JR. Diet, butyric acid and differentiation of gastrointestinal tract tumours. Med Hypotheses 1985; 18: 113-8.

5 Thornton JR. High colonic $\mathrm{pH}$ promotes colorectal cancer. Lancet 1981; 1: 1081-3.

6 Prasad KN. Butyric acid, a small fatty acid with diverse biological functions. Life Sci 1980; 27: 1351-8.

7 Kruh J. Effects of sodium butyrate, a new pharmacological agent on cells in culture. Mol Cell Biochem 1982; 42: 65-82.

8 Kim YS, Tsau D, Siddiqui Whitehead J, Arnstein P, Bennet J, Hicks J. Effects of sodium butyrate and dimethyl sulfoxide on biochemical properties of human colon cancer cells. Cancer 1980; 45: 1185-91.

9 Weaver GA, Krause JA, Miller TL, Wolin MJ. Short chain fatty acid distribution of enema samples from a sigmoidoscopy population: an association of high acetate and low butyrate ratios with adenomatous polyps and colon cancer. butyrate ratios with ade

10 Vernia P, Ciarniello P, Cittadini M, Lorenzotti A, Alesandrini A, Caprilli R. Stoool pH and SCFA in colorectal cancer and polyps. Gastroenterology 1989; 96: A528.

11 Clausen MR, Bonnen H, Mortensen PB. Colonic fermentation of dietary fibre to short chain fatty acids in patients with adenomatous polyps and colonic cancer. Gut 1991; 32: 923-8.

12 Burn J, Chapman P, Delhanty J, Wood C, Lalloo F, Gonzales $\mathrm{MB}$, et al. The UK Northern Region genetic register for familial adenomatous polyposis coli: use of age of onset familial adenomatous polyposis coli: use of age of onset curves, congenital hypertrophy of the retinal epithelium and 289-96.

13 McDougal EI. Studies on ruminant saliva. The composition and output of sheep's saliva. Biochem $\mathcal{F}$ 1948; 43: 99-108. Mathers JC, Fernandez F, Hill MJ, McCarthy PT, Shearer MJ. Dietary modification of potential vitamin K supply from enteric bacterial menaquinones in rats. Br f Nutr 1990; 63: 639-52.

15 Bodmer WF, Bailey CJ, Bodmer J. Localisation of the gene for FAP on chromosome 5. Nature 1987; 328: 614-6.

16 Fearon ER, Vogelstein B. A genetic model for colorectal tumorigenesis. Cell 1990; 61: 759-67.

17 Murday V, Slack J. Inherited disorders associated with colorectal cancer. Cancer Surv 1989; 8: 139-57.

8 Cummings $\mathrm{JH}$. Short chain fatty acids in the human colon. Gut 1981; 22: 763-79.

19 Cummings $\mathrm{JH}$. Colonic absorption, the importance of short chain fatty acids in man. Scand F Gastroenterol 1984; 93: 98-9. 
20 Walker ARP, Walker BF, Walker AJ. Faecal pH, dietary fibre intake and proneness to cancer in 4 South African populations. Br F Cancer 1986; 53: 489-95.

21 Pietroiusti A, Caprilli R, Guiliano S, Vita S. Faecal pH in colorectal cancer. Italian foumal of Gastroenterology 1985; 17: 88-91.

22 Pye G, Evans DF, Ledingham S, Hardcastle JD. Gastrointestinal intraluminal $\mathrm{pH}$ in normal subjects and those with colorectal adenoma or carcinoma. Gut 1990; 31: 1355-7.

23 Thornton JR, Dryden A, Kelleher J, Losowsky MS. Super efficient starch absorption, a risk factor in colonic neoplasia. Dig Dis Sci 1987; 32: 1088-91.

24 MacFarlane GT, Englyst HN. Starch utilisation by the human large intestinal microflora. 7 Appl Bacteriol 1986; 60: 195201.

25 Goodlad JS, Mathers JC. Effects of food carbohydrates on large intestinal fermentation in vitro. Proc Nutr Soc 1988; 47: $176 \mathrm{~A}$.

26 Lipkin M, Reddy BS, Wiesburger J, Schechter L. Non- degradation of faecal cholesterol in subjects at high risk for cancer of the large intestine $\mathcal{F}$ Clin Invest 1981; 67: 304-7. 27 Watne AL, Lai HL, Mance T, Core S. Faecal steroids and bacterial flora in patients with polyposis coli. Am $\mathcal{F}$ Surg 1976; 131: 42-6.

28 Spigelman AD, Owen RW, Hill MJ, Phillips RKS. Biliary bile acid profiles in familial adenomatous polyposis. $\mathrm{Br} \mathcal{F}$ Surg

29 Floch MH, Binder HJ, Filburn B, Gershengoren W. The effects of bile acids on intestinal microflora. Am $\mathcal{F}$ Clin Nutr 1972; 25: 1418-26.

30 Bartram HP, Scheppach W, Heid C, Kasper H. Effect of starch malabsorption on faecal bile acids and neutral sterols in humans: possible implications for colonic carcinogenesis. Cancer Res 1991; 51: 4238-42.

31 Reddy BS, Watanabe K. Effect of cholesterol metabolites and promoting effect of lithocholic acid in colon carcinogenesis 39: $1521-4$ 